\title{
Social Change of Bajo Tribe Society in Karimunjawa: From "Sea Tribe" to "Land Tribe"
}

\author{
Titiek Suliyati \\ Department of History, Faculty of Humanities, \\ Diponegoro University
}

\begin{abstract}
Known as sea tribe, Bajo tribe is foreigners in Karimunjawa. As a sea tribe, they are nomadic and live on boat before settling in Karimunjawa. The encouragement to settle in Karimunjawa is due to the fact that the island has a lot of fish and they exploit it to make their living. At the beginning they live on boat, but sometimes they move to the land. Later on they build houses on stilts at coastal areas.

The process experienced by Bajo tribe from sea to land tribe is caused by some factors, from the effort to adapt with local people, decreasing number of the captured fish, the government program to make Bajo tribe becomes the land settlers and the change of their livelihood.
\end{abstract}

Received:

19 December 2017

Accepted:

21 December 2017

Corresponding author:

suliyati.titiek@gmail.com

This research is aimed to study the social change occurring to Bajo tribe as a sea tribe that was formerly nomadic into land tribe dwelling in Karimunjawa. Moreover, this research also intended to study the push factors and the impact from the social change toward the live of the settled Bajo society. In line with the problem and the objectives of this research, qualitative method with the anthropological and sociological approach was used. These two approaches were applied in order to give a better understanding about the social change of Bajo tribe that had already settled in Karimunjawa.

The result of the research shows that there is a social change in Bajo society living permanently in Karimunjawa that is, the change of daily behavior in the society, social interaction with other tribes, values held by the society and social institution, structure and social classes. Social change occurring to Bajo society in Karimunjawa brings positive influences. The social changes among others are awareness towards the importance of education, Bajo society has new jobs other than fisherman, the increase of income, living standard, also modernization in fisheries system. The negative impact as a consequence of the social changes is faded culture, changes in life orientation and views of life, and consumerism in the society.

Keywords: Social change, Bajo tribe, sea tribe, land tribe, Karimunjawa

\section{Introduction}

Bajo tribe or often known as Bajo People is one of the maritime ethnic tribes in Indonesia who have uniqueness. As a maritime tribe, they live off the sea as traditional fishermen. The Bajo tribe is also known as nomads of the ocean. Because they always live by moving one place to another across the vast ocean, the Bajo tribe is also known as the nomadic tribe. It can be said that they have visited all Indonesian water. Bajo tribes can be found in several coastal areas of Indonesia such as in the waters of Makassar Strait, in Banggai Islands (east of Sulawesi), in the waters of Sulawesi (North Sulawesi), on the east coast of Kalimantan, East Kalimantan (East Sabah), in Bone gulf, in the waters of East Nusa Tenggara, in Tomini gulf, in the north Maluku (Bacan and Halmahera islands), in the Sulu 
archipelago. ${ }^{1}$ To find out the spread of the Bajo tribe, it can be seen from the results of Sopher's research, ${ }^{2}$ which states that some regions or areas in Indonesia have names that are related to the Bajo tribe, such as Labuhanbajo in Tomini Gulf, in Flores, in the eastern part of Sumbawa Island, in the gulf of Bima, on the east coast of Borneo, even in the Anambas Islands in the South China Sea.

As a sea tribe, Bajos people live in almost all coastal areas of Indonesia, including in Karimunjawa islands. The fact when the Bajo tribe began to settle in groups at Karimunjawa is in questionable. At the beginning of their voyage to Karimunjawa, the Bajo tribes only stopped by to get their shipping supplies. After a few stops and when they feel comfortable living on the shore of Karimunjawa, they then began to settle there. The village of Bajo tribe is located in Benteng village in the south of Karimunjawa. The Bajo community in Karimunjawa has a distinctive social stucture, cultural, custom and language that makes this community unique.

After many people of Bajo tribe began to settle in the shore of Karimunjawa, social changes occur. Social change that occurs in the society is very complex, not only caused by a single factor. In accordance with Bertrand, Bajo tribe in Karimunjawa also underwent very complex social changes, from adaptation to the local community, the decreasing number of captured fish, the government program that encouraged the Bajo tribe to settle in land, the changes of livelihood and so forth. ${ }^{3}$

According to Martono, ${ }^{4}$ changes can be a broad change (macro) including changes in social systems while micro changes are related to social interactions between individuals. As stated by Martono, the Bajo community in Karimunjawa also experienced these two kinds of changes that are from simple change, to a more complex changes and finally to the comprehensive changes. Their simple and modest lifestyle began to shift due to their intensive interaction with other societies, resulting in the infiltration of more modern values. Beside bring a good effect, this impact also gives bad effects which cause the local wisdom values of Bajo tribe to diminish.

This article is the result of a qualitative research using anthropology and sociology approaches. This is intended to provide a better understanding of the social changes happen in Bajo tribe. In the view of qualitative research, reality is formed through a social interaction (socially constructed) and therefore the purpose of qualitative research is basically to gain understanding of a subject from the point of view of the subject itself. This implies that this research approach requires a different set of assumptions if human behavior is approached for the purpose of obtaining facts for its causes. ${ }^{5}$

Overall, the data collection in this research is conducted through several techniques, namely; in-depth interview, focus group discussion (FGD), observation, and literature study. In-depth interviews were conducted to individual respondents using interview guidelines. The selection of respondents was determined using snowball sampling technique. FGDs were conducted on the respondents collectively to discuss various matters relating to social changes occuring in the community of Bajo Karimunjawa tribe.

Data analysis in this study used qualitative data analysis method, which is a search of common statements about the relationship between various data categories to build a

${ }^{1}$ Adrian B. Lapian, Orang Laut, Bajak Laut, Raja Laut: Sejarah Kawasan Laut Sulawesi pada Abad XIX, (Jakarta: Komunitas Bambu, 2009), p. 80.

${ }^{2}$ Lapian, Orang Laut, Bajak Laut, Raja Laut.

${ }^{3}$ Bertrand, 1980: 161.

${ }^{4}$ N. Martono, Sosiologi Perubahan Sosial: Perspektif Klasik, Modern, Posmodern, dan Poskolonial, edisi revisi (Jakarta: Rajawali Press, 2014).

${ }^{5}$ Bogdan, R.C. and Biklen, S.K., Qualitative Research for Education: An Introduction to Theory and Methods (Boston: Allyn and Bacon Inc., 1982). 
conceptual understanding of social reality based on the findings of empirical data. Patton explains that in a qualitative research, data analysis is the process of arranging the sequence of data, organizing it into a category pattern and in a basic description unit. Data categorization is adjusted to the formulation of the problem of the study and is intended to provide ease of interpretation, selection, and explanation in the form of analytical descriptions. ${ }^{6}$

\section{Bajo Tribe in Karimunjawa}

Bajo tribe is called as Bajo by common people, while the Bajo people refer to themselves as Sama. The Bajo people call another tribe as Bagai. People outside the Bajo tribe often interpret the name of Bajo as pirate. ${ }^{7}$ In various conditions, Bajo tribe is often referred to as Sea People, Bajo and Sama. To show their identity, Bajo tribe assumes that there are only two groups of people in this world, Sama and Bagai.

From their perspectives, the Sama is Bajo people living in the sea, both who live in boats and live in stilts houses on the sea. The Bajo people call themselves Sama because they have the same lifestyles, rules and norms. Bagai are the people living on land, who have various rules and norms and different cultures, which is in contrast to Sama. The Bajo people consider Sama as the Bajo people who still live in the sea, while Bajo people who have lived on land are considered to be Bagai, whose life is no longer the same as the Bajo people.

It is unclear when the first generations of the Bajo tribe have settled in Karimunjawa. From the beginning, Bajo people live in the southern Karimunjawa Islands, in the village Beteng to be exact.

Currently, the native Bajo tribe who resides in Karimunjawa is not more than 25 families. The native Bajo residents are no more than eight families, the rest are Bajo people who have married with other tribes (Java, Bugis, Madura).

Earlier, the Bajo tribe came in groups from the Bau-Bau to Karimunjawa. They feel comfortable when they arrived at Karimunjawa because they can find a livelihood and live a decent life as a fisherman. The Bajo fishermen then returned to Bau-Bau (South Sulawesi) to pick up their wives and children to move to Karimunjawa.

In their early live in Karimunjawa, a number of Bajo tribe lived on the boat with their family always accompanying when they go fishing. The boat function for Bajo people is the same as home, which is very important and valuable. Despite its function as a house, boat is the only means of transportation that they can carry wherever they go. This is in line with Zacot ${ }^{8}$ that every family of Bajo tribes always try hard to have a boat. The boat that became the home of the Bajo Karimunjawa tribe during sailing is known as leppa. The term leppa is also commonly found in Bajo tribes in other areas of Indonesia. In this leppa, Bajo tribe engages in their daily activities, ${ }^{9}$ as well as Bajo tribe in Karimunjawa. There is a unique thing in their tradition that when a baby born in a family, the baby was bathed with sea water and given a drink of sea water. This tradition is performed because they have a belief that the children will have a strong bond with the sea when they grow up.

${ }^{6}$ A.B. Marvasti, A.B., Qualitative Research In Sociology: An Introduction (London: Sage Publ. Inc., 2004).

${ }^{7}$ Lapian, Orang Laut, Raja Laut, Bajak Laut, p. 80-82.

${ }^{8}$ Francoise Robert Zacot, Orang Bajo Suku Pengembara Laut: Pengalaman Seorang Antropolog, translated by Fida Muljono-Larue and Ida Budi Pranoto (Jakarta: Kepustakaan Populer Gramedia-Ecole Francaise D'extreme-Orient, 2008), p. 127.

9Benny Baskara, Islam Bajo (Jakarta: Javanica, 2016), p. 37. 
According to Nimmo in Lapian, ${ }^{10}$ the community structure of Bajo people who still reside in boats can be distinguished into three levels, namely (1) mataan, (2) pagmundah, and (3) dakampungan. Mataan is the smallest unit, usually consisting of a nuclear family of father, mother and children. Pagmundah is a group of boats sailing and anchored together. Groups in Pagmundah usually have very close family relationships, for example comprising of extended family. Some mataan form a pagmundah, and some pagmundah form a dakampungan. ${ }^{11}$ A Dakampungan is a group of floating house boats and moving from one place to another. The social structure of the Bajo tribe in Karimunjawa when they first settled in Karimunjawa also similar to the structure of Bajo people living in other areas.

In the Bajo tribe, the kinship system plays a very important role since it becomes their identity which distinguishes between Sama and Bagai. Despite where they live, between the Bajo people they assume that they still have close relatives or bond. Bajo people from various regions belief that they still connected in kinship, such as the Bajo tribe in the Mola and Matinggola is related to Bajo tribes in Kupang, Rote, Karimunjawa, Malaysia, Philippines and many others. ${ }^{12}$ Similarly, with the Bajo tribe in Karimunjawa who believe that they still have kinship ties with the Bajo tribe in South Sulawesi (Bau$\mathrm{Bau}$ ).

Currently Bajo people in karimunjawa no longer live on the boat. They build stilts houses on the shallow water by the sea. Even though they no longer live on the boat, they still want to live co-existing with the sea. In the past, a government program was issued to provide homes for Bajo tribe on land, but this program was unsuccessful because of their character as a "sea people." The native Bajo people cannot live on land to date.

In contrast to fishermen from other tribes, the Bajo tribe has a unique way to hunt fish. They dive and catch fish, squid, clams and oyster using spear. Until now the people of Bajo tribe is known as the conqueror of the sea since they hold their breath for quite a long time in the water.

Due to their close bond with the marine life, Bajo people believe that there is a ruler or god of the sea. They believe that the sea must be preserved and respected because the sea has provided life for them. The popular saying among the Bajo tribe is "di lao 'denakangku' (ocean is my brother). The ocean is a place to live and make living that must be preserved and respected. Related to their close bond with the ocean, it is reflected in a proverb speaking pinde kulitang kadare, bone pinde sama kadare which means that moving the Bajo people to the land is similar to move turtles to the ground. ${ }^{13}$ Many of them even feel dizzy if they do not listen to the wave pound on the shore (piddi tikolo'na lamong nggai makale le goya).

They express their respect for the sea by giving offerings to the sea at certain times. ${ }^{14}$ The Bajo tribe believes that the sea is dominated by the sea gods they call as Mbo Ma Dilao. Mbo Ma Dilao consists of four gods, namely Mbo Janggo (the most powerful god), Mbo Tambirah, Mbo Goyah and Mbo Dugah. ${ }^{15}$ One habit in the Bajo tribe in Karimunjawa, that is when they go sailing and a storm breaks, they always call Mbo Janggo and Mbo Tambirah. They believe that Mbo Janggo and Mbo Tambirah are their ancestors who have become rulers of the sea, who will always protect them.

Although the Bajo tribe remains performing original Bajo customs and traditions, they are Moslems. It is questioned when and how the process of Islamization in the Bajo

\footnotetext{
${ }^{10}$ Lapian, Orang Laut, Bajak Laut, Raja Laut, p. 94.

${ }^{11}$ Lapian, Orang Laut, Bajak Laut, Raja Laut, p. 91-92.

${ }^{12}$ Baskara, Islam Bajo, p. 32-33.

${ }^{13}$ Nasruddin Suyuti, Orang Bajo di Tengah Perubahan (Yogyakarta: Penerbit Ombak, 1996), p. 51.

${ }^{14}$ Baskara, Islam Bajo, p. 230-233.

15Baskara, Islam Bajo, p. 185.
} 
tribe community. Many experts argue that the entry process of Islam into Bajo tribe is when they traveled across waters and met with leaders or rulers and Muslim communities, who then taught Islam to them. ${ }^{16}$ Their religious life is unique one since it is a blend of Islam with their original beliefs. They incorporate the core of Islamic teachings in their original custom, which then becomes their guidance in their lives. ${ }^{17}$ The changing process of the Bajo tribe in viewing their own tribe with and non-Bajo people indicates the process of life changing of the Bajo people from the sea tribe into the land. Bajo people no longer distinguish themselves with other people who are non-Bajo tribe. These changes give an impact on various aspects of their lives. Their culture gradually shifts to orient on non-Bajo society culture. The change occurred because the people of Bajo began to adapt to meet their needs. ${ }^{18}$

\section{The Change of the Bajo People in Karimunjawa from the Sea Tribe into Land Tribe}

The Bajo tribe in Karimunjawa is similar as Bajo tribes in other areas, proud of their lives life in the sea. Since they spent most of their time in the sea, the Bajo tribe has a great local wisdom on marine life. This develops a high pride and confidence in the Bajo tribe because of its uniqueness in applying their local wisdom related to life at sea. The local wisdom they master fosters the belief that they have immunity to illness, they have supernatural powers and are invincible. These are the reasons why the Bajo tribe initially refused to settle on land. To live on land as Bagai people (land people) means that they must obliged to the rules and authorities set by people outside their tribe, which will certainly fade their pride as a sea tribe away. The Bajo tribe in Karimunjawa in the 1970s began to experience difficulties associated with the declining number of sea resources, resulting in the decreasing income of the Bajo tribe. Another important thing was the existence issue of the Bajo tribe that became part of the Archipelagic State of The Indonesian Republic. As Indonesian, Bajo tribe must be subject to rules related to their citizenship, such as they must hold ID card. Similarly, in 1982 when the government issued a policy to relocate Bajo tribes who still live in the sea, a negative response arose from the Bajo tribe. This government effort was unsuccessful although the government has provided them with a plot of land to plant and harvest. Many Bajo tribes left their land and return to the sea.

The change of Bajo people lives in Karimunjawa continues as the sea products declining, the more unfriendly nature, and their encounters with the more prosperous land tribes; gradually altering the Bajo tribe determination to continue to survive in the sea. They begin to adapt to life on land. They realize that they do not want to continue as an illegitimate group of marginal people.

Bajo tribe in Karimunjawa who originally lived in boats on the beach and living a nomadic life, gradually began to build houses on stilts by the sea. At first, the houses were not actually built on the land, but some were still above surface the sea because the Bajo tribe could not really leave the sea. The Bajo people deliberately interact socially with other tribes living on the land. There are several reasons why the Bajo tribe in Karimunjawa wants to settle on land. The Bajo tribe was unsatisfied with the government policies which were considered neglecting their interests, so it has made them to live on the ground by perforce. To survive living in the sea, Bajo tribe requires goods that are only sold in the market. If they live wandering, it will be difficult to get their daily needs that are only available in the market. Therefore, they chose to live on land. Another cause is the more dangerous situation in the sea and the unpredictable weather, forcing them to face

16Baskara, Islam Bajo, p. 185.

${ }^{17}$ Baskara, Islam Bajo, p. 19.

${ }^{18}$ Suyuti, Orang Bajo, p. 20-11. 
the natural challenges and always adapt to these conditions. The more stable land-living became their choice. Moreover, the young generation of Bajo tribe is not as tough as its predecessor in facing challenges at sea. The knowledge and wisdom of Bajo's younger generation about the character of the sea is not as deep as their ancestors, so there is no choice but to settle on land.

\section{Social Change of Bajo Tribe in Karimunjawa}

The social change of Bajo people in Karimunjawa started from their change of settlement. The settlement of the Bajo people in Karimunjawa after the 1970s has changed from living on a boat to a permanent residence located on land or by the land. There are two types of Bajo settlements in Karimunjawa, which is a group of stilts house built on the surface of the sea along the seaside and houses built on land near the shore. The owners of the houses on stilts on the seashore are the elder members of the Bajo tribe community who still have a strong bond with the sea. There are also houses built on land located close to the shore. These houses-on-land were mostly built by the younger generation of Bajo. The houses of the Bajo tribe located on the land are brick houses made from building materials such as bricks and cement. In its development, the residence of Bajo tribe community formed a village.

Bajo tribe who have lived and settled in Karimunjawa have to adapt to other tribes that live there. As a tribe that natively live in the sea, Bajo tribe are gradually able to adapt to live on land.

Another social change, experienced by Bajo tribe in Karimunjawa is the change of livelihood. Formerly, Bajo tribe in Karimunjawa like Bajo tribes in other regions, make a living at sea based on working groups, namely: (1) Lilibu is a small group of Bajo fishermen. They go fishing on small boats, fishing in areas not too far away within one to two days; (2) Papongka is a group of Bajo fishermen who go to sea within one to two weeks in the deeper sea areas. (3) Sakai is a group of Bajo fishermen who sail to other islands for a longer time; (4) Lame is a group of Bajo fishermen who sail with large motorized boats and crew. They go to other countries for months.

As the sea product can no longer meet the needs of Bajo tribe, these groups begin to lose their income. Then, it forces them to seek other alternative livelihoods, while landbased labor such as farming is not their expertise. In the end, their choice is only working as a laborer on another person's fishing boat or working odd jobs, such as a small trader and sometimes also sailing.

Along with the development of tourism in Karimunjawa, many Bajo tribe younger generations work as a marine tourism guide, tourist boat driver, dive guide and trader of typical Karimunjawa food at night in the square.

Old people of Bajo tribe, who are no longer fishing at sea every day, have another job to be a "shaman" or fortune teller. They work as shaman or mystic because they have and practice mantras that are believed to cure the disease or solve the problems faced by people who come to ask for help.

After settled, Bajo peoplein Karimunjawa intensively interact with other tribes living in Karimunjawa. This social interaction is more profound when there is a marriage between the people of Bajo tribe and other tribes, such as Java, Bugis and Buton. Most of Bajo tribe married Javanese people. Many Bajo tribe men marry Javanese women, because according to Bajo people Javanese women are simple women who want to work hard, economical and can manage finance. The marriage between Bajo tribe with people from other tribes caused the culture from outside to enter Bajo culture. Therefore, the culture 
from outside Bajo (in this case is Javanese culture) also enrich Bajo culture. However, the customs and traditions of Bajo gradually begin to fade.

The social interactions of Bajo tribe who call themselves Sama and those outside Bajo (Bagai) gradually eliminate mutual disrespect. Now, Bajo people consider that people outside their tribe have the same status and position with them. Bajo people can mingle and interact with other tribe communities because they are very dependent on other tribe communities to meet their living needs, both food, clothing and livelihood tools. This social interaction also leads to the entry of other tribe cultures into Bajo culture. This social interaction also changes the daily use of language in Bajo tribe community. Previously, Bajo people only use Bajo language to communicate, but after they interact intensively with other tribe communities, Bajo people also understand the language of other tribes such as Java, Bugis, Buton, Madura and others. In interacting with other ethnic groups, Bajo communities use Indonesian language with Bajo or Sulawesi accent. Sometimes they also use informal Javanese language. In communicating with fellow Bajo tribe, they use Bajo language.

Another social change, experienced by Bajo people is the change of structure of organization and public institution. In the past, when Bajo people still lived in the boat and lead nomadic life, the composition of Bajo people is divided into mataan, pagmundah, and dakampungan. This community is led by a commander who is a tribal chief. After Bajo people settled, then they formed a wider group in the form of countryside, village, and even subdistrict. Bajo people in Karimunjawa must be subject to the administrative leadership of the state, namely Village Head and Sub-district Head, while the tribal chief only functions and participates in traditional ceremonies, celebration ceremony, healing ritual and so forth.

In the environment of native Bajo people there are social stratifications, high-class nobleman called Lolo Same, middle-class nobleman or noble who has mixed blood with another tribe called Ponggowa Same, ordinary people called Gallarang, and lower class community called Ate/Ata. In the past, Lolo Same and Ponggawa Same groups were not allowed to marry Gallarang, Atta or other tribe groups, as it would lower the two upper classes. The ideal marriage for Bajo tribe community is inter-kinship marriage, so that the kinship relationship between them is not interrupted and their social status is maintained. After Bajo tribe settled on land and mingled with various tribes, they no longer maintain inter-family marriages. Many of them get married to other tribes.

Social stratification in Bajo communities after settling on land is that it is no longer based on noble class, ordinary people and low class community, but based on the aspect of economic domination, i.e. capital owners and workers. In Karimunjawa, the capital owner or employer is a local resident from various tribes who acts as a leader in economic activity. Bajo people who rely on their strength, act as workers or subordinates, since they have no financial capital and production tools. This stratification leads to the creation of patron-klien relationship, i.e. local people or land people as capital owners for example in the form of fishing gear and boat, while Bajo people as workers or laborers.

In Karimunjawa there is a vertical social stratification that allows everyone to have an opportunity to improve their lives on their own merits. One of the sign of Bajo community standard in determining one's social status is the title of "hajj". This title indicates that a person has a high social and economic status. In the neighborhood, this person is rich and respected. Similarly, in work, Lolo Same and Ponggawa Same do not go to sea and wander with Gallarang and Ata Lolo Same and Ponggawa Same in Bajo community act and serve in religious, custom and marriage ritual aspect.

Bajo people in Karimunjawa also intensively interact with other tribes who live in Karimunjawa. Bajo tribe as a nomadic tribe has a great adaptation ability. Wherever Bajo 
tribe is, they try to adjust to the new environment and try not to make trouble with the community in the new place where they stop. Although Bajo peoplecan adapt to their environment, they still maintain their traditions, lifestyle, and local wisdom as a sea people. This social interaction is more profound when there is a marriage between Bajo peopleand other tribe communities, such as Java, Bugis and Buton.

In social activities, Bajo people always try to maintain harmony with other ethnic people. They realize that they are immigrants, so they do not want to create commotion and problem in the community. Although Bajo people can interact well with all people of other ethnic groups, but in the work as fishermen they prefer to work with Bajo people or those who still have family ties with them. It is because they have to understand each other's habits and traits. In addition, it is easier to apply the rules and distribution of fish catch.

Bajo people in Karimunjawa can be said to be all Muslims. From the very beginning when Bajo ancestors wandered to Karimunjawa, they had embraced Islam. Although they practice Islam, the older generations of Bajo tribe still perform Bajo native rituals and customs.

The holy verses of Qur'an are often included in rituals to cast out evil spirits or rituals to avert evil. In curing the diseases, Bajo shamans often use holy verses of Qur'an and mix it by reciting mantras. In addition, they also believe that when they go to sea, they always pray for salvation to God and their ancestors. One example, they always call Mbo Janggo and Mbo Tambirah/Mbo Jambirah when there is typhoon or storm at the sea. They believe that Mbo Janggo and Mbo Tambirah are their ancestors who have become the rulers of the sea and will always protect them.

Currently, Bajo young generations who do not understand anymore about the spiritual life taught by their ancestors, begin to practice the teachings of Islam better. They study religion through muslim forum held in mosques or lectures from kyai or ustad. Religious behavior is shown by Bajo people through the implementation of Islamic shari'a such as fard salat, fasting, zakat, Friday prayer in mosques and celebration of religious festivals.

In general, Bajo people including those in Karimunjawa are less concerned with the education of their children. Initially Bajo children did not get formal education. This is because the location of their residence on a boat that is always around the ocean. In addition, Bajo parents think that it is enough to give child an education at home by parents. Formal education is seen to only increase the economic burden. Bajo parents think that as long as the children can work in the sea and understand the marine life, then they can live prosperous. The lack of attention of Bajo parents on education of their children is also due to the early childhood that has been burdened to help the parent working at sea.

As a result of the lack of education, the life of Bajo people are not directed and organized, meaning they cannot plan, organize, and manage their work. Regardless of the number of fish they get, they cannot sell it for a reasonable price, as they sell their fish to a middleman. In addition, the income from the fish sale obtained at the time was spent immediately. It makes their life does not improve in terms of economy.

Condition in the past few years show changes in perceptions of Bajo parents on education. This change of perception is due to their association with other members of the community after they settled on land.

In recent years there have been many Bajo children who have studied in schools in Karimunjawa ranging from Kindergarten to Senior High School. The effect of education obtained by Bajo children in Karimunjawa is that they gain the knowledge and skills they can use in their future life. 
Local wisdom owned by Bajo tribe is that they have a unique way to catch fish. They dive and catch fish by spearing them. Until now, Bajo ethnic community is known as a skilled diver. How to catch fish like this is a local wisdom of Bajo tribe where they only catch fish according to their needs. This is to preserve the fish so as not to become extinct quickly.

Philosophy of the sacredness of the sea that aims to preserve the sea is: Papu manak ita lino bake contents-isina, kikiaja mamikira man bhatingga kolekna mangelolana. It means that God has given this world with all its contents; human beings think how to obtain and use it. Another philosophy that is often heard among Bajo tribes is di lao' denakangku' (the ocean is my brother). Ocean is a place to live and seek a livelihood that must be maintained and respected. These philosophies are firmly held by the older generation of Bajo tribe to preserve coral reefs as a buffer for marine ecosystems.

Bajo local wisdom is reflected in several traditional ceremonies, such as: (1) Duata Sangal ceremony, a traditional ceremony to release fish species that the population declines. Bajo people have the wisdom that they only catch big fish. Small fish caught in the net is released back to the sea; (2) Parika ceremony, an act providing space for fish to lay eggs and breed and limiting fishing by time agreed by customary leaders and figures of Bajo community; (3) Pamali, a ban on fishing in the "forbidden area" set by Bajo customary chief. If anyone violates Pamali, that person will be subject to sanctions; (4) Maduai Pinah, a ritual performed when Bajo fishermen back to the sea at pamali location

Because of the proximity with marine life, Bajo people believe that there is a ruler at the sea. They believe that the sea shall be preserved and respected, because the sea has given them a living. One of the respects they show for the sea is in the form of giving offerings at certain times. They also abstain from throwing waste and rubbish into the sea.

Another local wisdom is the ability to adapt to the environment, which can be seen from the form of house on stilt built on water. This house on stilt is the native house of Bajo tribe built from environmentally friendly materials.

Today, Bajo local wisdom is fading away. The Bajo younger generations no longer pay much attention to the rituals, traditions and philosophies associated with the preservation of marine resources. The orientation of Bajo younger generation is on the material things and very consumptive lifestyles. This is because the livelihood of Bajo younger generation is not focused on the sea anymore.

\section{Effects of Bajo Social Change on Bajo People and Community outside Bajo Tribe}

Social change in Bajo tribe community affects the internal of Bajo people and community outside Bajo tribe. The effect is that after they live on land, they socialize in harmony with other tribes. There is no difference between Sama and Bagai.

This change in social interaction also causes the entry of values and cultures outside Bajo tribe into Bajo community, so that Bajo native values and culture begin to fade away. In addition, modern values entered into Bajo community make them materialistic and consumptive.

Change in organization and social institutions affect the rules of state, village, until RT and RW level that shall be obeyed by Bajo people. Change in livelihood causes Bajo people to improve their skills in other jobs, because they cannot rely solely on the declining sea products.

Change in understanding religion affects the implementation of the rules of religion correctly, in accordance with the Islamic tenet and shari'a. Here, their life is not fully separable between custom and religion. 
Awareness of education for Bajo children provides positive effect, that is, Bajo young generation is expected to have knowledge and skills that can be the modal for their life in the future.

Local wisdom changes provide an effect on the fading of young Bajo understanding on the values or norms, traditions and indigenous cultures of Bajo tribe. This will gradually eliminate the character and characteristic of Bajo tribe as sea tribe.

The effect of Bajo social change on the community outside Bajo tribe is, tribes outside Bajo can learn from Bajo tribe about noble values related to marine conservation. In addition, adaptive attitudes toward the environment also benefit other tribes, so that they can live together harmoniously.

\section{Conclusion}

At first, Bajo people who have lived in Karimunjawa for a long time still bring their traditions and culture as tribes. At first, Bajo people in Karimunjawa lived in a boat anchored at the seaside. After a government program to "house" Bajo tribe on land, they started building houses on the seashore. Their native tradition of great respect for the sea was the local wisdom they continued to preserve. In making live, they relied on seafood. To keep the marine resources sustainable, they only took enough seafood, according to their needs. To preserve the marine resources, Bajo tribe performed traditions related to the offerings to the ruler of the sea. This traditional belief is still carried out, even though they have embraced Islam.

Bajo people in Karimunjawa had experienced social change as a result of social interaction with other tribe communities. The marriage of Bajo tribe members with the members of Javanese, Bugis, Madurese, Butonese and other tribe communities, brought social change within Bajo tribe. The marriage of Bajo tribe with other tribes brought a change in their culture and traditions. Their native traditions and local wisdom began to fade away. In addition, the changing of livelihoods of the Bajo younger generation, which no longer focus on the sea, also faded the native Bajo tradition as a sea tribe.

The social interaction of Bajo people in Karimunjawa with other tribes is harmonious. This harmonious social interaction results in the infiltration of modern values within Bajo people. These modern values begin to infiltrate the native tradition and local wisdom of Bajo tribe. The Bajo younger generations are no longer familiar with their native customs and traditions. These modern values lead to a change in the attitude of the Bajo younger generations into materialistic and consumptive people.

The condition of the sea where the resources begin to decrease makes Bajo tribe must find other alternatives to meet the needs of their life. Many Bajo younger generations work in trade, service sector as well as becoming laborers. To anticipate the progress and flow of modernization, most of Bajo people have realized the importance of education for their children. In order for the modernization to not give negative effects on the Bajo younger generation, the parents still teach the philosophies of life as the wisdom of Bajo tribe.

\section{References}

Lapian, Adrian B. Orang Laut, Bajak Laut, Raja Laut: Sejarah Kawasan Laut Sulawesi pada Abad XIX. Jakarta: Komunitas Bambu, 2009.

Martono, N. Sosiologi Perubahan Sosial: Perspektif Klasik, Modern, Posmodern, dan Poskolonial, revised edition. Jakarta: Rajawali Press, 2014. 
Bogdan, R.C. and Biklen, S.K. Qualitative Research for Education: An Introduction to Theory and Methods. Boston: Allyn and Bacon Inc., 1982.

Marvasti, A.B. Qualitative Research In Sociology: An Introduction. London: Sage Publ. Inc., 2004.

Zacot, Francoise Robert. Orang Bajo Suku Pengembara Laut: Pengalaman Seorang Antropolog, translated by Fida Muljono-Larue and Ida Budi Pranoto. Jakarta: Kepustakaan Populer Gramedia-Ecole Francaise D’extreme-Orient, 2008.

Baskara, Benny. Islam Bajo. Jakarta: Javanica, 2016. 